\title{
Effect of Foliar Nitrogen and Optical Sensor Sampling Method and Location for Determining Ornamental Cabbage Fertility Status
}

\author{
Bruce L. Dunn ${ }^{1}$ \\ Department of Horticulture and Landscape Architecture, Oklahoma State \\ University, $358 \mathrm{Ag}$ Hall, Stillwater, OK 74078-6027
}

\section{Carla Goad}

Department of Statistics, Oklahoma State University, Stillwater, OK 740786027

Additional index words. Brassicaceae, SPAD, atLEAF, controlled-release fertilizer, greenhouse, plant growth

\begin{abstract}
Leaf nitrogen (N) and contact optical sensor sampling methods vary in the literature. Thus, the objective of this study was to determine the best sampling procedure for correlating leaf $\mathbf{N}$ concentration to contact optical sensor readings. To investigate this, fertilizer rates of $0,5,10$, or $15 \mathrm{~g}$ of $16 \mathrm{~N}-9 \mathrm{P}-12 \mathrm{~K}$ were applied as a topdress application on ornamental cabbage (Brassica oleracea L.) 'Tokyo Red'. Soil plant analysis development (SPAD) and atLEAF chlorophyll meters were used every week for 5 weeks starting 30 days after planting. For each pot, SPAD and atLEAF measurements were taken from a single mature leaf from the middle to upper level of the plant at the leaf tip, blade, or base of the leaf not including the midrib. Weekly leaf foliar analysis consisted of collecting either fully developed leaves from a single plant, five plants, or 10 plants per, using only the tip, blade, or base of three leaves for total leaf $N$ concentration per treatment. A significant position affect was seen in both SPAD and atLEAF sensors. For SPAD, sensor readings taken from the tip and blade of a leaf were not significantly different from each other but were significantly different from the base of the leaf. All three positions for atLEAF were significantly different from each other. This indicates that sensor sampling location within a leaf will affect readings. A significant difference was observed among leaf sampling methods. Taking leaf samples from the tip and base had the highest leaf $N$ concentrations and were not significantly different from each other but were significantly different from all other sampling methods, which were not significantly different from each other. Significant correlations were seen among all combinations of sensor positions and leaf $\mathrm{N}$ sampling methods except SPAD readings taken from the tip and leaf sampling from a single plant. Highest correlations $(r=0.7$ to 0.8$)$ were seen when SPAD readings were taken from the base of the leaf irrespective of leaf sampling method. Based on this experiment, either sensor could be used for correlating leaf $\mathrm{N}$; however, growers should consistently collect sensor readings from the same location on a leaf to achieve consistent values and correlations.
\end{abstract}

Ornamental cabbage (Brassica oleracea var. capitata L.) and kale (Brassica oleracea var. acephala) are divided into groups based on leaf characteristics with cabbage having smooth leaf margins and kale having divided or fringed leaf margins and both are often grown as fall crops (McAvoy, 1994; Smith, 2004). Both respond to moderate fertilizer levels. For potted production, 150 to $300 \mathrm{mg} \cdot \mathrm{L}^{-1}$ constant liquid feed or a $12 \mathrm{~N}-10 \mathrm{P}-17 \mathrm{~K}$ slowrelease fertilizer applied at transplanting is recommended for potted production (Gibson and Whipker, 2000; McAvoy, 1994). Multiple applications totaling 168 to $224 \mathrm{~kg} \mathrm{~N} / \mathrm{ha}$ is

Received for publication 9 Sept. 2014. Accepted for publication 12 Nov. 2014.

${ }^{1}$ To whom reprint requests should be addressed; e-mail bruce.dunn@okstate.edu. levels in crops with short production schedules. Also, growers often do not have a large number of plants for destructive measurements; therefore, nondestructive methods of determining chlorophyll content and $\mathrm{N}$ status are of interest to growers (Wang et al., 2004). Use of optical sensors allows for an increased number of plants and leaves to be analyzed and results are immediately available (Mielke et al., 2012). The SPAD (SPAD-502; Konica Minolta, Japan) is widely accepted in the agronomic industry as an indicator for chlorophyll content and crop N status (Loh et al., 2002) and has been used on various horticultural crops. Westerveld et al. (2003) found that SPAD readings in cabbage were correlated with total leaf $\mathrm{N}$ concentrations at the heading stage, whereas Wang et al. (2012) reported that Normalized Difference Vegetation Index and SPAD optical sensors were found to correlate with greenhouse-grown geraniums (Pelargonium $\times$ hortorum). The SPAD meter contains a red and an infrared light-emitting diode to measure chlorophyll absorbance ( 650 $\mathrm{nm}$ ) and nonchlorophyll absorbance (940 nm), respectively, although a new and cheaper alternative chlorophyll meter, atLEAF (FT Green LLC, Wilmington, DE), measures chlorophyll absorbance and nonchlorophyll absorbance at $660 \mathrm{~nm}$ and $940 \mathrm{~nm}$, respectively. Both SPAD and atLEAF instruments measure light transmission through a small area of the leaf, $2 \times 3 \mathrm{~mm}$ and $9 \times 9 \mathrm{~mm}$, respectively, while in contact with the sensor. Leaf chlorophyll content and chlorophyll meter readings are often correlated with leaf $\mathrm{N}$ content and photosynthetic capacity (Evans, 1983; Seemann et al., 1987; Wang et al., 2004). However, other researchers have reported that chlorophyll sensors are not a suitable substitute for foliar analysis and are not correlated to leaf $\mathrm{N}$ content or concentration (Reeves et al., 1993; Rodriguez and Miller, 2000; Sibley et al., 1996; Westerveld et al., 2003). This could be related to the wide distribution of chlorophyll within a leaf as a result of chloroplast arrangement and light conditions (Azia and Stewart, 2001; Nauš et al., 2010).

Sensor sampling location within a leaf is not consistent among published research in the literature (Bonneville and Fyles, 2006) and sometimes not even reported. Anderson et al. (1993) reported a need for standard sampling procedures because sensor sampling location on a leaf affected readings in corn (Zea mays L.). Sensor readings are often correlated back to leaf $\mathrm{N}$ concentration, yet leaf $\mathrm{N}$ sampling procedures also vary in the literature from number of leaves used, location of leaves used, and how many plants represent a sample. This may account for variability when correlating plant $\mathrm{N}$ status and chlorophyll meter readings. According to Mickelbart (2010), evaluating nutrient status in crops requires careful consideration of leaf collection practices designed to collect the most representative sample from a plot or group of plants. Therefore, the objectives of this study were to determine the effects of varying the position of chlorophyll sensor readings (tip, blade, base) on a leaf, if leaf 
$\mathrm{N}$ concentration varies according to leaf sampling method, and determine the best sampling technique for correlating leaf $\mathrm{N}$ concentration to contact optical sensor readings.

\section{Materials and Methods}

Plant material and growth conditions. On 7 Aug. 2013, 288 cell tray plugs (two to four leaves) of ornamental cabbage 'Tokyo Red' were obtained from Park Seed Co. (Greenwood, SC). A single plug was transplanted $5 \mathrm{~d}$ later into standard $(15.2 \mathrm{~cm}$ diameter and $1.35 \mathrm{~L}$ volume) pots with $\approx 0.35 \mathrm{~kg} 902$ Metro-Mix media (Sun Gro Horticulture, Bellevue, WA), which has an initial starter charge of $\approx 0.5$ $\mathrm{mg} \cdot \mathrm{dm}^{-3}$ of total $\mathrm{N}$ and other macronutrients and micronutrients. Plants were grown in the Oklahoma State University Department of Horticulture and Landscape Architecture Research Greenhouses at Stillwater, OK, under natural photoperiods. Temperature was set at $18 / 21^{\circ} \mathrm{C}$ day/night with a photosynthetic photon flux density range of 600 to $1200 \mu \mathrm{mol} \cdot \mathrm{m}^{-2} \cdot \mathrm{s}^{-1}$ at $1200 \mathrm{HR}$.

Treatment conditions. On 19 Aug. 2013, fertilizer rates of $0,5,10$, or $15 \mathrm{~g}$ of $16 \mathrm{~N}-9 \mathrm{P}-12 \mathrm{~K}$ (Osmocote ${ }^{\circledR}$ Plus 3-4 month; The Scotts Co., Marysville, $\mathrm{OH}$ ) were applied as a topdress application, and tap water was then used during irrigations. Pots were hand-watered at a rate that allowed media saturation and $\approx 20 \%$ leaching. Nitrogen treatments were designed to produce plants with $\mathrm{N}$ status ranging from deficient to excessive with $0,0.75,1.5$, and $2.25 \mathrm{~g} \mathrm{~N}$ rates

$S P A D$, atLEAF, plant growth, and leaf $N$ content determination. A SPAD chlorophyll meter (SPAD-502; Konica Minolta) and atLEAF chlorophyll meter (FT Green LLC) were used to measure individual plants from the same 10 pots per treatment every week (total of five rating dates) in the morning starting $30 \mathrm{~d}$ after planting by clapping onto a leaf or placing a leaf in the devices aperture, respectively. For each pot, SPAD and atLEAF readings were taken from a single mature leaf from the middle to upper level of the plant either at the leaf tip, from the middle of the leaf not including the midrib, or toward the bottom of the leaf not including the midrib. Leaf foliar analysis was conducted on samples from six different sampling collection methods: 1) collecting all fully developed leaves from a single plant (eight to 10 leaves); 2) three leaves from five different plants per treatment and bulked; 3) three leaves from 10 different plants per treatment and bulked; 4) using only the tip portion (top $\approx 1.5 \mathrm{~cm}$ ) of three leaves from 10 different plants per treatments; 5) using only the middle portion (blade $\approx 2.0$ to $2.5 \mathrm{~cm}$ ) of three leaves from 10 different plants per treatments; or 6) using only the bottom portion (base $\approx 2.0 \mathrm{~cm}$ ) of three leaves from 10 different plants per treatment without petioles for total leaf $\mathrm{N}$ per sampling treatment weekly. Leaf samples were analyzed for total $\mathrm{N}$ content $\left(\mathrm{g} \cdot \mathrm{kg}^{-1} \mathrm{DM}\right)$ by the Soil, Water and Forage Analytical Laboratory at Oklahoma State University using a LECO TruSpec Carbon and Nitrogen Analyzer
(LECO Corporation, St. Joseph, MI). At the end of the study, data were collected on the same 10 plants for height (from the top of the pot to the highest point), width (average of two perpendicular measurements), and shoot weight (stems cut at media level) and then dried for $2 \mathrm{~d}$ at $52.2{ }^{\circ} \mathrm{C}$.

Statistics. Pots were arranged in a completely randomized design with 10 replications. Continuous response variables of SPAD, atLEAF, and leaf $\mathrm{N}$ variables were analyzed using Tukey's method of linear mixed models for repeated measures across the 5-week period and/or for the position on the leaf for the atLEAF and SPAD sensor positions. Plant height, width, and dry weight response variable were only measured at the end of the 5-week study. Post hoc analysis of the means was conducted using Tukey pairwise comparisons. Correlation analyses of SPAD and atLEAF readings with the different leaf $\mathrm{N}$ samples were also computed. Tests of significance were performed at the $0.001,0.01$, and 0.05 levels. The data analysis for this article was generated using SAS/STAT software, Version 9.3 (SAS Institute, Inc., Cary, NC).

\section{Results and Discussion}

No significant interactions were seen among $\mathrm{N}$ rate $\times$ sensor leaf location, $\mathrm{N}$ rate $\times$ week, week $\times$ sensor leaf location, or $\mathrm{N}$ rate $\times$ sensor leaf location $\times$ week for either sensor; however, fertilizer rate and leaf position as main effects were significant (Tables 1 and 2). Readings from both sensors were not different among the various fertilizer rates but were different from the control treatment (Tables 1 and 2). The control treatment was different from any treatment receiving fertilizer for height, width, and dry weight (Table 3 ). However, all three variables increased with increasing fertilizer rates with the 10 - and 15-g treatments not showing differences for height and dry weight and the 5-, 10-, and 15-g treatments not showing any difference for plant width (Table 3). Dunn et al. (2014) also reported similar findings for ornamental kale 'Nagoya Red' in which 10-, 15-, and 20-g fertilizer rates were not different for height and width and no difference was observed for fresh weight among the 5-, 10-, 15-, and 20 -g fertilizer rates at $53 \mathrm{~d}$ after treatment. Gibson and Whipker (2000) reported no differences in height among fertilizer rates and differences between the lowest fertilizer rate of $150 \mathrm{mg} \cdot \mathrm{L}^{-1}$ and the two higher rates of 200 and $250 \mathrm{mg} \cdot \mathrm{L}^{-1}$ after B-Nine foliar applications for ornamental kale

Higher SPAD readings were observed in the tip and blade positions and were not different from each other but were different from the base position for SPAD. Lower readings at the base of the leaf may be a result of leaf architecture with the base of the leaf being shaded and having reduced access to direct light. Nauš et al. (2010) reported that chlorophyll distribution within a leaf is affected by chloroplast arrangement and light conditions. Anderson et al. (1993) noted SPAD reading differences between the middle and tip positions on corn (Zea mays) with the middle position being most stable, although Hamblin et al. (2014) reported consistent SPAD measurements among five evenly spaced points on three different wheat (Triticum aestivum $\mathrm{L}$.) and barley (Hordeum vulgare L.) plants with a single slow-release fertilizer application. All three sensor position locations were different for atLEAF indicating that sensor sampling position can affect readings (Table 2). Gond et al. (1999) also reported that chlorophyll concentration varied within needle position of Scots pine (Pinus sylvestris L.)

Table 1. Soil plant analysis development (SPAD) chlorophyll sensor measurements on ornamental cabbage 'Tokyo Red' for different fertilizer rates per pot of 16N-9P-12K slow-release fertilizer and different sensing locations on a leaf for five dates after fertilizer treatment (DAT).

\begin{tabular}{lccccc}
\hline $\begin{array}{l}\text { Fertilizer rate } \\
(\mathrm{g})^{* * * \mathrm{z}}\end{array}$ & $\begin{array}{c}\text { SPAD value } \\
\text { (unitless) }\end{array}$ & $\begin{array}{c}\text { Sensor leaf } \\
\text { location*** }\end{array}$ & $\begin{array}{c}\text { SPAD value } \\
\text { (unitless) }\end{array}$ & $\begin{array}{c}\text { Week } \\
\text { (DAT) NS }\end{array}$ & $\begin{array}{c}\text { SPAD value } \\
\text { (unitless) }\end{array}$ \\
\hline 0 & $44.4 \mathrm{~b}^{\mathrm{y}}$ & Tip & $53.2 \mathrm{a}$ & 23 & $51.3 \mathrm{a}$ \\
5 & $51.4 \mathrm{a}$ & Blade & $52.2 \mathrm{a}$ & 30 & $50.1 \mathrm{a}$ \\
10 & $52.4 \mathrm{a}$ & Base & $46.3 \mathrm{~b}$ & 37 & $51.2 \mathrm{a}$ \\
15 & $54.0 \mathrm{a}$ & & & 44 & $50.5 \mathrm{a}$ \\
& & & & 51 & $49.6 \mathrm{a}$ \\
\hline
\end{tabular}

${ }^{\mathrm{z}}$ Main effects nonsignificant (Ns), ${ }^{*} P \leq 0.05, * * P \leq 0.001$, or $* * * P \leq 0.0001$.

${ }^{\mathrm{y}}$ Means $(\mathrm{n}=10)$ within a column followed by the same letter are not significantly different by Tukey's method $(P \leq 0.05)$.

Table 2. atLEAF sensor measurements on ornamental cabbage 'Tokyo Red' for different fertilizer rates per pot of $16 \mathrm{~N}-9 \mathrm{P}-12 \mathrm{~K}$ slow-release fertilizer and sampling at different locations on a leaf for five dates after fertilizer treatment (DAT).

\begin{tabular}{lccccc}
\hline $\begin{array}{l}\text { Fertilizer rate } \\
(\mathrm{g}) * * * \mathrm{z}\end{array}$ & $\begin{array}{c}\text { atLEAF value } \\
\text { (unitless) }\end{array}$ & $\begin{array}{c}\text { Sensor leaf } \\
\text { location*** }\end{array}$ & $\begin{array}{c}\text { atLEAF value } \\
\text { (unitless) }\end{array}$ & $\begin{array}{c}\text { Week } \\
(\mathrm{DAT}) *\end{array}$ & $\begin{array}{c}\text { atLEAF value } \\
\text { (unitless) }\end{array}$ \\
\hline 0 & $51.7 \mathrm{~b}^{\mathrm{y}}$ & Tip & $57.8 \mathrm{a}$ & 23 & $57.7 \mathrm{a}$ \\
5 & $57.4 \mathrm{a}$ & Blade & $56.6 \mathrm{~b}$ & 30 & $55.0 \mathrm{~b}$ \\
10 & $58.0 \mathrm{a}$ & Base & $54.5 \mathrm{c}$ & 37 & $56.8 \mathrm{ab}$ \\
15 & $58.1 \mathrm{a}$ & & & 44 & $56.1 \mathrm{ab}$ \\
& & & & 51 & $55.9 \mathrm{ab}$ \\
\hline
\end{tabular}

${ }^{\mathrm{z}}$ Main effects nonsignificant (Ns), ${ }^{*} P \leq 0.05,{ }^{*} P \leq 0.001$, or $* * * P \leq 0.0001$

${ }^{y}$ Means $(\mathrm{n}=10)$ within a column followed by the same letter are not significantly different by Tukey's $\operatorname{method}(P \leq 0.05)$. 
with higher values at the tip and lower values at the base. Barton (2000) suggested that biotic or abiotic factors can cause changes in the chlorophyll distribution pattern, and Lizaso et al. (2003) suggests that chlorophyll in an individual leaf can vary depending on growth or expansion and/or longevity or senescence within a leaf. For SPAD, week effects were not different, but for atLEAF, weeks were significant indicating greater accuracy in detecting changes in leaf $\mathrm{N}$ concentration (Tables 1, 2, and 4). Cultivar differences, sampling location, and number of readings can effect accuracy, because Dunn et al. (2014) had significant week

Table 3. Response of ornamental cabbage 'Tokyo Red' to four fertilizer rates per pot of $16 \mathrm{~N}-9 \mathrm{P}-$ 12 slow-release fertilizer $51 \mathrm{~d}$ after fertilizer treatment.

\begin{tabular}{lccr}
\hline $\begin{array}{l}\text { Fertilizer } \\
\text { rate }(\mathrm{g})\end{array}$ & $\begin{array}{c}\mathrm{Ht} \\
(\mathrm{cm})\end{array}$ & $\begin{array}{c}\text { Width } \\
(\mathrm{cm})\end{array}$ & $\begin{array}{r}\text { Dry } \\
\text { wt }(\mathrm{g})\end{array}$ \\
\hline 0 & $11.7 \mathrm{c}^{\mathrm{z}}$ & $21.7 \mathrm{~b}$ & $8.7 \mathrm{c}$ \\
5 & $14.9 \mathrm{~b}$ & $32.5 \mathrm{a}$ & $30.7 \mathrm{~b}$ \\
10 & $16.8 \mathrm{a}$ & $33.1 \mathrm{a}$ & $39.3 \mathrm{a}$ \\
15 & $17.6 \mathrm{a}$ & $33.9 \mathrm{a}$ & $49.8 \mathrm{a}$ \\
\hline
\end{tabular}

${ }^{\mathrm{z} M e a n s}(\mathrm{n}=10)$ within a column followed by the same letter are not significantly different by Tukey's method $(P \leq 0.05)$.

Table 4. Leaf nitrogen $(\mathrm{N})$ concentration $\left(\mathrm{g} \cdot \mathrm{kg}^{-1} \mathrm{DM}\right)$ measurements on ornamental cabbage 'Tokyo Red' for different fertilizer rates per pot of $16 \mathrm{~N}-9 \mathrm{P}-12 \mathrm{~K}$ slow-release fertilizer and different sampling locations on a leaf for five dates after fertilizer treatment (DAT).

\begin{tabular}{lclccc}
\hline $\begin{array}{l}\text { Fertilizer } \\
\text { rate }(\mathrm{g}) * * * \mathrm{z}\end{array}$ & $\begin{array}{c}\text { Leaf } \mathrm{N} \\
\left(\mathrm{g} \cdot \mathrm{kg}^{-1} \mathrm{DM}\right)\end{array}$ & $\begin{array}{c}\text { Sampling } \\
\text { method***y }\end{array}$ & $\begin{array}{c}\text { Leaf } \mathrm{N} \\
\left(\mathrm{g} \cdot \mathrm{kg}^{-1} \mathrm{DM}\right)\end{array}$ & $\begin{array}{c}\text { Week } \\
(\mathrm{DAT}) * * *\end{array}$ & $\begin{array}{c}\text { Leaf N } \\
\left(\mathrm{g} \cdot \mathrm{kg}^{-1} \mathrm{DM}\right)\end{array}$ \\
\hline 0 & $2.3 \mathrm{~d}^{\mathrm{x}}$ & Tip & $3.9 \mathrm{a}$ & 23 & $4.3 \mathrm{a}$ \\
5 & $3.2 \mathrm{c}$ & Blade & $3.7 \mathrm{a}$ & 30 & $4.3 \mathrm{a}$ \\
10 & $4.1 \mathrm{~b}$ & Base & $3.4 \mathrm{~b}$ & 37 & $3.5 \mathrm{~b}$ \\
15 & $4.6 \mathrm{a}$ & Single plant & $3.4 \mathrm{~b}$ & 44 & $2.8 \mathrm{c}$ \\
& & Five plants & $3.4 \mathrm{~b}$ & 51 & $2.8 \mathrm{c}$
\end{tabular}

${ }^{\mathrm{z}}$ Main effects nonsignificant (NS), ${ }^{*} P \leq 0.05, * * P \leq 0.001$, or $* * * P \leq 0.0001$.

${ }^{\mathrm{y}}$ Mature leaves and no petioles were taken. Sampling included taking eight to 12 leaves from a single plant, three leaves from five different plants, three leaves from 10 different plants, collecting $\approx 1 \mathrm{~cm}$ from the leaf tips using five leaves from 10 different plants, $\approx 3$ to $4 \mathrm{~cm}$ from the middle or blade of the leaf using five leaves from 10 different plants, or $\approx 2 \mathrm{~cm}$ from the base portion of the leaf using five leaves from 10 different plants per treatment per week.

'Means $(\mathrm{n}=10)$ within a column followed by the same letter are not significantly different by Tukey's method $(P \leq 0.05)$.

$\mathrm{DM}=$ dry matter. related to a decline in photosynthetic activity as leaf age increases (Wilson and Cooper, 1969). Zhang et al. (2008) reported leaf $\mathrm{N}$ content per unit area and per unit mass decreased with increasing leaf age in alpine orchid (Cypripedium flavum P.F. Hunt et Summerh). Campbell (2000) reported foliar N sufficiency ranges should be 3.5 to $4.5 \mathrm{~g} \cdot \mathrm{kg}^{-1}$ $\mathrm{DM}$ in ornamental cabbage, which is consistent with findings from this experiment because the 0 - and 5-g fertilizer treatments showed $\mathrm{N}$ deficiency symptoms (purpling with a lighter almost gray leaf color occurring initially with the lower leaves then seen throughout the canopy). Gibson and Whipker (2000) reported similar $\mathrm{N}$ deficiency results for plants fertigated at $100 \mathrm{mg} \cdot \mathrm{L}^{-1}$.

All sensor positions and leaf $\mathrm{N}$ sampling methods showed significant correlations except for sensor readings taken from the leaf tip and leaf $\mathrm{N}$ samples from a single plant when all weeks were combined (Table 5). Along with leaf position, Loh et al. (2002) noted that leaf age, sampling time, nutrient interactions, and complex source-sink relationships can affect the ability to detect $\mathrm{N}$ content. For SPAD, correlating values with leaf $\mathrm{N}$ showed greater correlations for all leaf sampling methods when values were taken from the base of the leaf (Table 5). Westerveld et al. (2003) noted greater correlations between SPAD readings and leaf $\mathrm{N}$ in cabbage when sample number increased. Although leaf sampling location was not given in that study, results from this study indicated that sampling location can affect correlations with leaf $\mathrm{N}$. The atLEAF sensor showed greater correlations between sensor position and leaf sampling method when either the leaf tip or blade was used. This indicates sensor position plays a more important role in leaf $\mathrm{N}$ correlations than do sampling procedures. This supports Monje and Bugbee (1992) who noted that the location on the leaf sampled using a SPAD chlorophyll meter can result in readings that vary up to $50 \%$ and affected accuracy and reproducibility in rice (Oryza sativa L.), soybean [Gyycine max (L.) Merr.], and wheat (Triticum aestivum). Both sensors were correlated with each other with

Table 5. Pearson correlation ( $r$ ) matrix for measured sensor parameters for ornamental cabbage 'Tokyo Red' across five sampling dates $(\mathrm{n}=20)$.

\begin{tabular}{|c|c|c|c|c|c|c|c|c|c|c|c|c|}
\hline & SPAD tip & $\begin{array}{l}\text { SPAD } \\
\text { blade }\end{array}$ & $\begin{array}{l}\text { SPAD } \\
\text { base }\end{array}$ & $\begin{array}{l}\text { atLEAF } \\
\text { tip }\end{array}$ & $\begin{array}{l}\text { atLEAF } \\
\text { blade }\end{array}$ & $\begin{array}{l}\text { atLEAF } \\
\text { base }\end{array}$ & $\begin{array}{l}\text { Leaf } \\
\text { tip }^{z}\end{array}$ & $\begin{array}{c}\text { Leaf } \\
\text { blade }^{z}\end{array}$ & $\begin{array}{l}\text { Leaf } \\
\text { base }^{z}\end{array}$ & Single plant ${ }^{2}$ & $\begin{array}{c}\text { Five } \\
\text { plants }^{\mathrm{z}}\end{array}$ & $\begin{array}{c}\text { Ten } \\
\text { plants }^{\mathrm{z}}\end{array}$ \\
\hline SPAD tip & & $0.833 * * *$ & $0.713 * *$ & $0.779 * * *$ & $0.768 * * *$ & $0.778 * * *$ & $0.463 *$ & $0.483^{*}$ & $0.480 *$ & $0.435 \mathrm{NS}$ & $0.520 *$ & $0.506^{*}$ \\
\hline SPAD blade & & & $0.728 * *$ & $0.810^{* * *}$ & $0.852 * * *$ & $0.769^{* * *}$ & $0.606^{* *}$ & $0.597 * *$ & $0.631^{* *}$ & $0.571^{* *}$ & $0.621 * *$ & $0.634^{* *}$ \\
\hline atLEAF tip & & & & & $0.854 * * *$ & $0.784 * * *$ & $0.637 * *$ & $0.644 * *$ & $0.629 * *$ & $0.670^{* *}$ & $0.672 * *$ & $0.680^{* *}$ \\
\hline atLEAF blade & & & & & & $0.867 * * *$ & $0.600^{* *}$ & $0.614 * *$ & $0.641^{* *}$ & $0.641 * *$ & $0.663 * *$ & $0.695^{* *}$ \\
\hline atLEAF base & & & & & & & $0.475^{*}$ & $0.502 *$ & $0.510^{*}$ & $0.605^{*}$ & $0.510^{*}$ & $0.542 *$ \\
\hline Leaf base & & & & & & & & & & $0.892 * * *$ & $0.971 * * *$ & $0.974 * * *$ \\
\hline Single plant & & & & & & & & & & & $0.881 * * *$ & $0.908^{* * *}$ \\
\hline Five plants & & & & & & & & & & & & $0.980^{* * *}$ \\
\hline
\end{tabular}

${ }^{\mathrm{z}}$ Mature leaves and no petioles were taken. Sampling included taking eight to 12 leaves from a single plant, three leaves from five different plants, three leaves from 10 different plants, collecting $\approx 1 \mathrm{~cm}$ from the leaf tips using five leaves from 10 different plants, $\approx 3$ to $4 \mathrm{~cm}$ from the middle or blade of the leaf using five leaves from 10 different plants, or $\approx 2 \mathrm{~cm}$ from the base portion of the leaf using five leaves from 10 different plants per treatment per week.

y Pearson correlation $(r)$ significant at $P \leq 0.05$. Nonsignificant (NS), $* P \leq 0.05, * * P \leq 0.001$, or $* * * P \leq 0.0001$.

$\mathrm{SPAD}=$ soil plant analysis development; $\mathrm{N}=$ fertilizer. 
$r$ values ranging from 0.768 to 0.852 (Table 5). Although correlated, atLEAF and SPAD readings were different. This experiment showed an average reading difference of 5.5 between the two sensors with atLEAF always producing higher readings. Zhu et al. (2012), using five agronomic crops, indicated a difference of 10 between atLEAF and SPAD readings. Sensor reading location, number of readings taken per plant, cultivar effects, and environmental conditions could account for the variability. All leaf $\mathrm{N}$ sampling methods were highly correlated with each other with $r$ values ranging from 0.881 to 0.990 (Table 5).

Based on this experiment, either sensor could be used for correlating leaf $\mathrm{N}$, but location of sensor position on a leaf will affect values and correlations. Researchers should report in detail how contact sensor readings were obtained and growers should consistently collect sensor readings from the same location or results may be meaningless for future recommendations. Collecting leaf samples for foliar analysis is destructive, time-consuming, and requires sufficient sample sizes. This experiment showed that collecting leaves from a single plant was found to be as accurate as taking leaves from multiple plants for a composite sample. Because this was only one species and cultivar, future research should investigate if these results are applicable to other species, chlorophyll meters, sensor positions, data collection times, and leaf sampling procedures.

\section{Literature Cited}

Anderson, D., G. Johnson, and C. Taets. 1993. Evaluation of the Minolta SPAD-520 chlorophyll meter for on-farm $\mathrm{N}$ management of corn in Illinois. IL Fert. Conf. Proc. 4 Sept. 2014. $<$ http://frec.ifca.com/1993/report14/>.

Azia, F. and K.A. Stewart. 2001. Relationship between extractable chlorophyll and SPAD values in muskmelon leaves. J. Plant Nutr. 24:961-966.

Barton, C.V.M. 2000. A theoretical analysis of the influence of heterogeneity in chlorophyll distribution on leaf reflectance. Tree Physiol. 21:789-795.

Bonneville, M.-C. and J.W. Fyles. 2006. Assessing variations in SPAD-502 chlorophyll meter measurements and their relationships with nutrient content of trembling aspen foliage. Commun. Soil Sci. Plant Anal. 37:525-539.
Campbell, C.R. 2000. Reference sufficiency ranges for plant analysis in the southern region of the United States. Southern Coop. Ser. Bull 394:115-116.

Dunn, B.L., A. Shrestha, and C. Goad. 2014. Use of non-destructive sensors to quantify ornamental kale nitrogen status. J. Plant Nutr. accepted.

Evans, J.T. 1983. Nitrogen and photosynthesis in the flag leaf of wheat. Plant Physiol. 72:297-302.

Gibson, J.L. and B.E. Whipker. 2000. Revising the fertilization strategy for ornamental cabbage. NCSU State Hort. Res. Ser. No. 143. p. 1-4.

Gibson, J.L. and B.E. Whipker. 2003. Ornamental cabbage quality improved by continual fertilization through center-head coloration. HortScience 38:1381-1384.

Gond, V., D.G.G. de Pury, F. Veroustraete, and R. Ceulemans. 1999. Seasonal variations in leaf area index, leaf chlorophyll, and water content; scaling-up to estimate fAPAR and carbon balance in a multilayer, multispecies temperate forest. Tree Physiol. 19:673-679.

Hamblin, J., K. Stefanova, and T.T. Angessa. 2014. Variation in chlorophyll content per unit leaf area in spring wheat and implications for selection in segregating material. PLoS One 9:1-9.

Lea-Cox, J. 2000. The role of environmental risk assessment in developing nutrient management plans for nursery and greenhouse operations. Proc. S. Nursery Assn. Res. Conf. 45:77-80.

Lizaso, J.I., W.D. Batchelor, and M.E. Westgate. 2003. A leaf area model to simulate cultivarspecific expansion and senescence of maize leaves. Field Crops Res. 80:1-17.

Loh, F.C.W., J.C. Grabosky, and N.L. Bassuk. 2002. Using the SPAD 502 meter to assess chlorophyll and nitrogen content of Benjamin fig and cottonwood leaves. HortTechnology 12:682-686.

McAvoy, R.J. 1994. Cultural tips for ornamental cabbage and kale. CT Greenhouse Newsletter No. 180. p. 13-15.

Mickelbart, M.V. 2010. Variation in leaf nutrient concentrations of freeman maple resulting from canopy position, leaf age, and petiole inclusion. HortScience 45:428-431.

Mielke, M.S., B. Schaffer, and A.C. Schilling. 2012. Evaluation of reflectance spectroscopy indices for estimation of chlorophyll content in leaves of a tropical tree species. Photosynthetica 50:343-352.

Monje, O.A. and B. Bugbee. 1992. Inherent limitations of nondestructive chlorophyll meters: A comparison of two types of meters. HortScience 27:69-71

Nauš, J., J. Prokopová, J. Řebíček, and M. Špundová. 2010. SPAD chlorophyll meter reading can be pronouncedly affected by chloroplast movement. Photosynth. Res. 105:265-271.
Reeves, D.W., P.L. Mask, C.W. Wood, and D.P. Delaney. 1993. Determination of wheat nitrogen status with a hand-held chlorophyll meter: Influence of management practices. J. Plant Nutr. 16:781-796.

Ristvey, A., J. Lea-Cox, and D. Ross. 2001. Nitrogen partitioning and loss in container production systems. Proc. S. Nursery Assn. Res. Conf. 46:101-107.

Rodriguez, I.R. and G.L. Miller. 2000. Using a chlorophyll meter to determine the chlorophyll concentration, nitrogen concentration, and visual quality of St. Augustine grass. HortScience 35:751-754.

Seemann, J.R., T.D. Sharkey, J. Wang, and C.B. Osmond. 1987. Environmental effects on photosynthesis, nitrogen-use efficiency, and metabolite pools in leaves of sun and shade plants. Plant Physiol. 84:796-802.

Senger, E., A. Peyrat, M. Martin, and J.M. Montes. 2014. Genetic variation in leaf chlorophyll content of Jatropha curcas L. Ind. Crops Prod. 58:204-211.

Sibley, J.L., D.J. Eakes, C.H. Gilliam, G.J. Keever, W.A. Dozier, Jr., and D.G. Himelrick. 1996 Foliar SPAD-502 meter values, nitrogen levels, and extractable chlorophyll for red maple selections. HortScience 31:468-470.

Smith, T. 2004. Flowering cabbage and kale. 9 July 2014. <http://extension.umass.edu/floriculture/ fact-sheets/flowering-cabbage-and-kale>

Wang, Q., J. Chen, and Y. Li. 2004. Nondestructive and rapid estimation of leaf chlorophyll and nitrogen status of peace lily using a chlorophyll meter. J. Plant Nutr. 27:557-569.

Wang, Y., B.L. Dunn, D.B. Arnall, and P. Mao 2012. Use of an active canopy sensor and SPAD chlorophyll meter to quantify geranium nitrogen status. HortScience 47:45-50.

Westerveld, S.M., A.W. McKeown, C.D. ScottDupree, and M.R. McDonald. 2003. Chlorophyll and nitrate meters as nitrogen monitoring tools for selected vegetables in southern Ontario. Acta Hort. 627:259-266.

Wiedenfeld, R.P. 1986. Rate, timing, and slowrelease nitrogen fertilizers on cabbage and onions. HortScience 21:236-238.

Wilson, D. and J.P. Cooper. 1969. Apparent photosynthesis and leaf characters in relation to leaf position and age, among contrasting Lolium genotypes. New Phytol. 68:645-655.

Zhang, S.B., H. Hu, and Z.R. Li. 2008. Variation of photosynthetic capacity with leaf age in an alpine orchid, Cypripedium flavum. Acta Physiol. Plant. 30:381-388.

Zhu, J., N. Tremblay, and Y. Liang. 2012. Comparing SPAD and atLEAF values for chlorophyll assessment in crop species. Can. J. Soil Sci. 92:645-648. 